\title{
Neoliberal Crisisis, Social Demands, and Foreign Policy in Kirchnerist Argentina*
}

Anabella Busso**

\section{Abstract}

Traditionally, Argentine foreign policy has been regarded as the domain of the executive, and a laudable expression of realism. Perspectives that include domestic variables as a source of foreign policy have only emerged relatively recently, and have only assumed importance in a redemocratised Argentina in the course of its recurrent economic and political crises in the late $20^{\text {th }}$ and early $21^{\text {st }}$ century. This dynamic was particularly marked during and after the crisis of 2001. As a result, Kirchnerist foreign policy was affected by a range of complex domestic factors. The aim of this article is to show how those factors drove the governments of Néstor and Cristina Kirchner, without abandoning executive primacy, to prioritise a neodevelopmental economic model, and combine them with an autonomous foreign policy which they believed to be the only way to meet the social demands of those affected by the neoliberal crisis.

Keywords: Foreign Policy; Public Policy; Crisis; Domestic Constraints; Kirchnerism.

\footnotetext{
* Received on 16 October 2015 and approved for publication on 14 January 2016.

** National Council of Scientific and Technical Research, Buenos Aires, and National University of Rosario, Rosario, Argentina; gmarini@netizen.com.ar.
} 


\section{Introduction}

The influence of domestic factors and social demands over foreign policy is more evident in a redemocratised Argentina. Previously, when foreign policy was still being made in the realist tradition, it was conceived as an elite activity, intended to address and respond to systemic factors alone.

Events over the past 30 years prove that, besides external influences, foreign policy has been permanently affected by domestic constraints that have impacted on its contents and its level of politicisation. This is closely related to the successive crises Argentina has experienced since 1983, most seriously in 2001, which can be described as akin to a 'state collapse'.

Poor governance, social demonstrations, unemployment, poverty, debates about development, income redistribution, the strategic orientation of international insertion, the roles played by means of communication, the financial sector, entrepreneurs, and agricultural producers were among the actors and spheres of activity that affected public policy, including foreign policy.

The governments of Néstor and Cristina Kirchner - who served as successive presidents from 2003 until 2015 - reinforced this trend by prioritising internal needs as determinants of foreign policy. The negotiations over how Argentina should emerge from its debt default, including rescheduling its debt repayments, conformed to a neodevelopmental economic model, a unique way to meet the social demands of those who had been affected by the neoliberal crisis, and a signature feature of Kirchnerism.

Meanwhile, Néstor Kirchner argued that 'politics' was the only tool that could lift Argentina out of crisis, with the state and public policy playing a central role. At the same time, the government recognised 
the need to restore and restructure the linkages between state and society, which had been badly damaged in the 2001 collapse.

In this context, Argentina's external projection had to be refocused to align with its domestic needs, despite the fact that this would bring the country into conflict with a large number of international actors with whom it had enjoyed cordial relations in the 1990s.

This approach, which was initially supported by most of Argentinean society, began to change in the course of government action. Internal attempts to reshape the economic and political model as well as its international implications resulted in sharp differences between some domestic political parties and the government. In turn, this turbulence in domestic politics had direct and indirect impacts on foreign policy.

Both the complex internal situation subsequent to 2001 and the political debates in Argentina in the following 12 years created a framework in which domestic politics played a growing role in foreign policy formation. Given this, the Kirchner governments advanced the idea of a strong relationship between social interests and needs and external activities. This cannot be regarded as a fundamental shift towards foreign policy formation by means of social demands and democratisation, or even a diminution of central decision-making by the executive.

However, it can be argued that any analysis of Argentine foreign policy in this period must take into account the internal political situation, pressures exerted by domestic actors, and the linkages between state and society. This detracted from foreign policy's 'exceptional' status as detached and delinked from domestic political dynamics, and driven by external factors.

Similar trends in other South American countries in the $21^{\text {st }}$ century, notably the advent of the 'Pink Tide', have led scholars to argue that, in contrast with the past, foreign policy should be conceived as public 
policy (Lima 2013), subject to the same domestic influences and demands as other state policies. This suggests, as argued by Rosenau (1967) and Putnam (1988) some time ago, that foreign policy should be regarded as the product of permanent interaction between the internal and international environments, and not only of systemic influences.

Consequently, we agree with Milani and Pinheiro (2013: 12) that foreign policy requires 'research parameters that comprise the various parties in the decision-making process in its most diverse forms of participation, taking into account the variety of models of political interaction (influence, participation, co-operation, resistance, conflict)'.

In this article, I seek to provide a preliminary insight into this dimension by analysing how and why domestic dynamics gained growing influence over foreign policy in the Kirchner years, notably by aligning it more closely with internal social demands. To this end, I have selected a set of concepts (neoliberal crisis, state collapse, public policy, domestic constraints, foreign policy, democratically oriented foreign policy, and international insertion) that will be unpacked and interlinked to help us gain an understanding of this process.

I will start by analysing why the practice and analysis of foreign policy as public policy appear late in Argentina. Following this, I address the impact of the 2001 economic crisis on foreign policy. Next, I deal specifically with the influence of domestic factors over Kirchnerist foreign policy. Lastly, I provide some conclusions.

\section{Argentine foreign policy as public policy}

While some South American scholars are focusing increasingly on analysing foreign policy as public policy (Lima 2013; Milani and 
Pinheiro 2012, 2013; Busso 2010; Belém Lopes 2013), others claim this is neither necessary nor relevant, as this status is self-evident. The first approaches do not disclaim the formal status of foreign policy as public policy; however, they emphasise the relative lack of social influence over foreign policy formation, which sets it apart from the interactions between state and society on other public policies. Oszlak and O'Donnell (1981: 6) describe public policy as:

a set of actions and omissions that reveals a certain form of state intervention in relation with an issue that draws the attention, interest and mobilization of other parties of the civil society. Out of that intervention, it can be inferred a certain directionality, a purposive regulatory orientation, which foreseeably affect the future social process already developed around that issue.

In this perspective, every public policy links three dimensions, namely the political, administrative and social spheres, in that it responds to social requirements or needs, is developed mainly in the political domain, and is executed by the state administration (Salazar Vargas 2009).

Therefore, as noted earlier, conceiving foreign policy as public policy implies focusing on domestic actors and their relations with the state. This is necessary in order to analyse the impact of domestic dynamics on foreign policy, which affects not only its politicisation and democratisation, but also its contents. However, caution should be exercised in establishing a simple causal link between domestic actors and social, political and economic dynamics on the one hand, and a 'democratically oriented foreign policy' on the other. In this regard, we agree with Belém Lopes (2013: 8) that

its conceptualisation should remain open and be developed throughout accounts, be nurtured by a variety of practices and ideas, and pay 
attention to the minimalist approach that considers a sound appreciation of the possibilities that the population of a State endowed with democratic institutions has so as to influence - and, ultimately, condition - the course of its own foreign policy.

In Argentina, this approach has not featured prominently in political practice or academic work. Consequently, it is appropriate to ask why it has emerged at such a relatively late stage, and in lockstep with redemocratisation. I argue that the answer points to multiple causes, which shed light on the question in turn. These include the primacy of certain foreign policy theories, the global distribution of power, and domestic institutional instability and constitutional rights.

As regards the primacy of certain theories, it is well-known that the internationalist epistemic society regards the realist school as the main paradigm for the interpretation of international relations up until the 1970s. In terms of classical realism, foreign policy is determined exclusively by international factors, with public policy a state response to the threats and opportunities presented by the external context. In this perspective, the state is a "unified and rational actor that adopts a foreign policy as a reflection of the risks and situations presented in the international system - global or regional - aiming at maximizing its interest' (Lasagna 1996: 45). Consequently, as noted by Lima (1994), foreign policy formation is a relatively discrete process, isolated from the society in which it takes place. To this should be added the elitist conception in classical realism of those who are in a position to think about the world, and identify and defend the national interest in this context. In this view, this is the proper task of statesmen, supported by specialised bureaucracies. In contrast with other public policies, social participation is not taken into account, and is even regarded as harmful. 
Argentine academics were influenced by the classical realist school, and drew on it extensively to explain foreign policy in the 1980s. By contrast, while classical realism also predominated in the USA, it coexisted with liberal theories, which linked foreign policy to features of the domestic political system which were separate from the state, and with behavioural ones, which encouraged studies of the domestic decision-making process. In Argentina, the realist influence detracted from other approaches.

However, it is necessary to mention national and regional theoretical approaches which, flowing from various disciplines and ideological convictions, place constraints on the realist consolidation. In the case of Argentina, these include Prebisch's development theory, and Puig's autonomy theory. Brazilian academics who engaged with dependency theory as well as Jaguaribe's fruitful ideas include Dos Santos, Furtado, Marini and Cardoso. What those theories have in common is their concern with national development, and the need for greater political autonomy. They suggest that external political and economic policy should be used to address domestic issues, and include not only to domestic but also systemic variables.

Positive results of the import substitution policy proposed by the developmentalists and the political and academic interest in dependency theory faded away with the advent of the conservative neoliberal model of Reagan and Thatcher in the early 1980s. Those new ideas radiated out into the globalised world of the 1990s, enabling the pre-eminence of 'unique thought' and 'democracies by default ${ }^{1}$ which led to the depoliticisation of civil society. However, the crisis of the neoliberal model in Argentina opened the door to greater social mobilisation as well as the recovery of political and economic concepts forming part of 'South Theory'. The latter were regularly mentioned by the Kirchner governments when they argued for the need to link foreign policy to domestic needs and interests. 
On the other hand, the distribution of power at the global level also strengthened the notion that foreign policy responds mainly to systemic influences. This was more evident to weak states than to powerful ones. In this framework, beyond Argentina's initial international insertion as the 'granary of the world', it was also described as a 'developing country' and therefore, from the perspective of the Economic Commission for Latin America and the Caribbean (CEPAL), part of the periphery, thereby perpetuating the debate over an appropriate international insertion scheme (Miranda 2001, 2012). The persistence of political problems as well as low levels of development gave rise to the perception that Argentine foreign policy was largely shaped by the influence of the great powers and major international economic and financial actors (Russell 1991). In other words, the prevailing ideas stressed that developing countries were battling with a situation in which the power was somewhere else, and the range of foreign policy alternatives was limited.

Those perceptions were empirically supported. The regional experiences of independent foreign policies related to local development needs, or imbued with new ideologies, had to cope with the constraints imposed by the major powers. ${ }^{2}$ This gave the debate about systemic versus domestic influences over foreign policy a philosophical and political rather than an empirical character. Therefore, a paradox appears. While focusing on external factors as the main drivers of foreign policy formed part of a critical view of the major powers, downplaying the importance of domestic factors delimited the formation of both foreign policy and public policy and their subsequent democratisation.

Another central factor in delimiting social participation in political processes was institutional instability, linked to authoritarian government. Policy formation influenced by democratic interaction between state and society did not exist in Argentina for many years. 
Likewise, the violence exercised by the military regimes curtailed advances in terms of political participation and the consolidation of civil society achieved in the democratic periods before each coup d'etat (Garretón 1982; Borón 1983; Simonoff 2010; Rapoport 2010).

In this situation, both the type and quality of the political system not only drove foreign policy away from society, but also strengthened the theoretical and methodological premise that their proximity was the exclusive purview of developed democracies. In this perspective, local interest in foreign policy in those countries were challenged and legitimised by the institutional mechanisms in those countries. Thus, active parliaments, institutionalised lobbies, and the presence of policy think-tanks were regarded as important mechanisms for transmitting a range of social and economic interests, enabling them to reach the state and be taken into account in the design of public policies. That experience was not easily transferred to developing countries such as Argentina due to their dictatorships, lower levels of institutional consolidation, and their relative lack of public and private institutions connecting local needs and interests with foreign policies and initiatives.

Finally, the Argentine constitution enables the concentration of decisions about foreign policy in the executive, which tends to draw the foreign policy debate away from the parliamentary arena. As noted by Tokatlian and Merke (2014: 254), the president is the person who is in charge of foreign policy, which is delegated by the provinces to the federal government. The president signs international agreements (article 11), commands the armed forces (article 12), declares war, with the approval of Congress (article 15), and declares a state of siege in case of an external attack (article 16). Although the constitutional reform of 1994 aligned the country with the international recognition of human rights (article 75, section 22), the president enjoys wide latitude for determining the country's international orientation. 
For Tokatlian and Merke (2014), the presidential system, the electoral codes, and the competition between the Chancellery and other ministries dealing with the external agenda have relegated diplomacy to a secondary position, reducing its autonomy, and enabling a parallel bureaucracy (Tokatlian and Merke 2014: 269)

In sum, the four aspects noted above explain why, prior to redemocratisation, Argentine foreign policy was located in the executive, with no social participation; and why academics prioritised systemic conditionalities over domestic ones, and viewed foreign policy as essentially distinct from other public policies. In this context, it is clear that the state did not take into account the interests of civil society (Oszlak and O'Donnell 1981) or the social component of public policy (Salazar Vargas 2009).

\section{Crisis and foreign policy}

In May 2003, Néstor Kirchner assumed office in an atmosphere of crisis and a domestic situation that had significant implications for foreign policy. In fact, these factors were not unique to the Kirchner years, but arose from the broader process of Argentine redemocratisation. In 1983, Raul Alfonsín took over the government after seven years of military rule, a period characterised by the violation of human rights, economic liberalisation and de-industrialisation, growing foreign debts, and increasing inflation. In addition, losing the Falklands War to Great Britain hampered Argentina's international integration.

Likewise, Carlos Menem assumed office in 1989 amid a hyperinflation crisis in which prices rose by almost $5000 \%$ in a single year (Bulner 2003), forcing a sharp devaluation and spiralling interest rates. Growing social demands related to the growing gap between prices and salaries as well as pressures from the corporate 
and financial sectors and the mass media had forced Alfonsín to step down (Rapoport 2010).

In this framework, domestic factors played a key role in Menem's successful presidential campaign, during which he acknowledged social discontent and promised to launch a 'productive revolution', and enable a major increase in salaries (salariazo). These factors also played an important role in the reformulation of foreign policy, causing a shift towards alliances with political parties and economic actors of the centre-right politico-economic tradition. ${ }^{3}$

This trend was also based on the Menem administration's perceptions of global shifts and the need to reform the Argentine economy, which became a central consideration in formulating public policy, including foreign policy. Notably, this amounted to a recognition of a post-Cold War order of rampant globalisation, the predominance of market economies, and US global leadership. Therefore, in order to improve its international insertion, Argentina had to live 'in tune with the time' (Menem 1990), inter alia by aligning its foreign policy with Washington and the neoliberal economic criteria prevailing worldwide in the 1990s (Busso 2014).

Although the economic and financial crisis of 1989-90 was as severe as that of 2001, and shared some features such as high levels of public spending without access to finance, a public debt crisis, capital flight, and rising social demands, they were not identical. While in both cases the institutional difficulties led the president handing over power earlier, in the second crisis this process involved five presidents in a single week, a social demand of 'everybody out!', and quasi-currencies.

On the other hand, Menemism involved a different approach to domestic impacts on foreign policy than Kirchnerism. While Menem believed that Argentina's economic problems should be solved by 
creating a transnationalised economy rather than concentrating on self-generated development, Kirchner supported the latter option.

Kirchner inherited the 2001 crisis, regarded as the worst in Argentine history for its consequences at the political, economic, institutional and social levels. Thus, international loan defaults, quasi-currencies, unemployment, poverty, difficulties in maintaining sound governance, a deterioration of the presidential image, and social mistrust of politics had all contributed to the widespread sense of despair and disillusionment present in May 2003 when he assumed office.

In fact, it could be argued that Argentina was on the way to becoming a collapsed state (Corigliano 2007). This can be assessed against five of the ten indicators suggested by Pauline H Baker and John A Ausink (1996), ${ }^{4}$ as follows:

1) Uneven economic development: From October 2001 to October 2002, the number of poor people grew by 600000 people per month (according to the National Institute of Statistics and Censuses (INDEC). From May to October 2002 alone, the proportion of people living in poor households increased from $53 \%$ (19.1 million people) to $57.5 \%$ (20.81 million people). Of those, 9.95 million were indigent (Bermúdez 2003). This situation affected the most vulnerable, but also the middle and lower middle classes.

2) Serious economic problems related to a lack of political stability: Towards the end of the De La Rúa government, Argentina could no longer get any external credit. As a result, the government introduced limits on the withdrawal of money from bank accounts, which became known as the corralito (playpen). Between the resignation of De La Rúa on 20 December 2001 and 2 January 2002, Argentina had four presidents. Debt repayments were suspended (the biggest default ever). The equivalence between the peso and the dollar 
was terminated, and an asymmetric pesification system was adopted.

3) Mass, chronic, or sustained human exoduses: In Argentina, this took the form of the emigration of scientists and other economically active citizens. According to Lelio Mármora (as quoted in Dandán 2002), by the year 2000 some 600000 Argentineans were living abroad. In the next two years (2000-2001), 160000 more left the country. Among the four migration waves in the history of Argentina, the last-named one, which started in 2001, corresponded with the highest level of unemployment, and was fuelled most strongly by the media, which constantly referred to the national breakdown (Dandán 2002).

4) The progressive deterioration of public services. During and after the 2001 crisis, public services in Argentina deteriorated significantly. A lack of investment by private companies that had received concessions in the 1990s and the failure of the state to exercise its control functions affected electricity, water and transport. Furthermore, the massive social demonstrations limited the free movement of people in the big cities and along domestic routes, thereby exacerbating perceptions of ungovernability.

5) Suspension of the rule of law. Followed the massive social demonstrations referred to as cacerolazos (casserole), during which people banged on pots and pans; the looting of shops; and the popular rejection of politicians encapsulated in the slogan 'Everybody out!', De La Rúa declared a state of siege during the last days of his administration. On 19 and 20 December 2001, security forces killed 39 people, including nine children.

According to these indicators, then, the Argentine state showed clear signs of collapsing, largely because of a crisis of neoliberalism, with 
poverty, exclusion, migration, a mistrust of politics, institutional weakness, widespread social demands, and anomie among the symptoms. According to Garretón, the challenge in Latin America after the crises of the 1990s was 'rebuilding the relationships between State and society, and the possibility of building a capability of carrying out political actions to deal with the globalized world and internal fragmentation' (Garretón 2006: 112). This was the challenge Kirchner sought to address in Argentina. Among other things, it led to domestic needs and demands being prioritised as a source of foreign policy.

\section{Foreign policy, international insertion, and internal constraints during the Kirchner administrations}

The crisis of 2001 provided a framework for the government of Néstor Kirchner. The complex and urgent internal agenda had a major impact on foreign policy, as the latter was now regarded as a tool for resolving domestic problems. While neither Néstor nor Cristina Kirchner stated this explicitly, it can be inferred from their speeches and from Argentina's international insertion under their administrations. ${ }^{5}$

This approach echoes Lafer, who states that the purpose of foreign policy should be to help address local needs and interests. Consequently, 'translating internal needs into external possibilities so as to extend the society's control of their destiny is the focal point of foreign policy as public policy, and this implies the assessment of the specificity of the problems, needs and interests from a perspective that comprises the national common good, which is not a simple task' (Lafer 2002: 21). Lafer's assertion leads to a central debate in Argentina between economic liberalism, which 
encourages modalities of insertion that favour the dominant power, and developmentalism, which is associated with the quest for autonomy (Pignatta 2010).

Kirchnerism adhered to the second perspective, and introduced a quest for autonomy associated with an inclusive industrial development model. Therefore, Argentina's international insertion was not conceived as a process for the accumulation of power derived from the relationships and alignments with powerful actors, but as a process derived from the concept that a country projects itself from the inside to the outside. Ferrer's notion of 'national density' (2010) reflects this vision by positing a strong relationship between the solidity of internal political and economic conditions and chances of success in meeting international challenges. In this view, Argentina is still a country under construction, and therefore needs to strengthen its 'national density' if it is to move forward. This requires social cohesion, strong leadership, institutional and political stability, critical thinking about social reality, and sound economic policies. According to Ferrer, successful countries have always take steps to increase their 'national density', thereby demonstrating that strong states are built from the inside out and not the other way round (Ferrer 2010).

In this framework, the Kirchner administrations sought to improve social cohesion by reducing poverty, increasing employment, and accelerating the redistribution of income. At the same time, they succeeded in vindicating politics, and recovering presidential leadership. Furthermore, they were critical of the current international order, opposing the double standards of powerful states, the speculative pressures exerted by the international financial sector, and the constraints imposed by multilateral financial institutions (notably the IMF and World Bank), and vindicated multilateralism and the importance of regional space. Finally, they adhered to the neo-developmental tendency which emerged in South 
America in the first decade of the $21^{\text {st }}$ century, which sought to foster national development on an industrial basis.

Domestic factors play a central role in these conceptions of foreign policy and international insertion. They are usually defined typologically, in terms of a series of domestic variables (Van Klaveren 1992, Russell 1991). These factors influence foreign policy via the activities of domestic actors, and also via socio-economic dynamics. The latter influence may be temporary or permanent, and may be more or less relevant depending on the context.

Therefore, recognising the role of domestic factors in foreign policy should involve describing the historical moment, identifying the relevant domestic actors, and analysing the pressures exerted by the different sectors that are trying to mould their country's external conduct in their own interests.

An examination of some of Néstor Kirchner's foreign policy milestones (renegotiating external debt, dealing with the gas crisis, introducing a human rights policy, and dealing with the paper mills crisis) reveals domestic factors at work in each instance, whether the policy outcome was supported by society or not, and whether the initiative was taken by the state or by society.

\section{The renegotiation of external debt}

As regards the renegotiation of Argentina's external debt between 2003 and 2005, Kirchner stated that it should affect neither Argentina's development nor job creation. In his first speech to the UN General Assembly, he declared: 'Without concrete international assistance, without measures that foster sustainable growth and development, the payment of the debt becomes a real chimera', and 
warned that he would not allow creditors to suffocate him. He used to say, 'Nobody can collect a debt from the dead' (Kirchner 2003b). Similarly, the then minister of economic affairs, Roberto Lavagna (2005), claimed that 'without growth with social inclusion, it is impossible to sustain a payment scheme'.

The debt negotiations, supervised by the president together with the Ministry of Economic Affairs, and assisted by the Chancellery, was complex, as it involved confrontations with private creditors, the G-7, and the transnational financial system, as well as tough negotiations with the IMF. However, domestic actors were co-operative. Society at large agreed with the president's diagnosis of the responsibilities of certain external actors for the national collapse. The industrial and agricultural sectors believed that, due to the complex economic period they were going through, the government's pro-development position and protection of internal markets were appropriate.

Finally, in those years, hegemonic communications also supported the process of debt re-negotiation. As noted by Becerra (2015), by 2003 the corporate media were essentially bankrupt. Invoking the need to retain jobs, Kirchner granted them important concessions, ${ }^{6}$ thereby gaining their support until the end of his administration. Sovereign debt, the central topic of foreign policy until March 2005, was successfully restructured, in terms of which $76 \%$ of government bonds were exchanged at lower nominal values and brought out of default, and the agreements were supported domestically. A second restructuring in 2010 increased the percentage of bonds under some form of repayment to $93 \%$.

\section{The gas crisis}

The 2004 gas crisis involving Chile is another example of the role of domestic factors in foreign policy. Due to a lack of investment by 
privatised companies in the 1990s, and the freezing and pesification of tariffs after the 2001 economic crisis, Argentina had to cope with tensions between the supply of and demand for gas. Kirchner dealt with this by prioritising local industrial and household needs, and reducing gas exports to Chile. The Chilean government believed this decision broke the gas protocol signed by the two countries in 1995 . However, the Argentine authorities said this was not the case because the protocol stated that gas would be exported as long as this would not jeopardise the local market. Faced with a domestic energy crisis, Argentina began to import gas from Bolivia, accepting the condition imposed by Carlos Mesa's government that its gas should not be exported to third countries. Due to a long-standing tensions between Bolivia and Chile, the Bolivian president's intention was 'not to supply Chile with a molecule of gas' (Agramont 2012).

In the course of the resultant diplomatic dispute, the Argentine public understood that the measures taken were aimed at protecting their needs and interests, while some journalists and members of opposition parties expressed mild criticism by publishing the Chilean claims, or emphasising the need for economic integration with neighbouring states. The results of Kirchner's decision were varied: on the one hand, domestic demands were satisfied and the national development process was not interrupted; on the other, bilateral relations with Chile were damaged and a phase of co-operation with Bolivia was opened, which, despite gains and losses, continued for some time.

\section{Recognition of human rights}

Human rights organisations in Argentina vigorously combated the state terrorism which had occurred during the periods of authoritarian rule. The advent of democracy and the military trials helped Argentine society to partly overcome the painful past, and introduced important measures for moving towards truth, justice and 
memory. However, repeated threats of a military coup d'etat led Raul Alfonsín to prioritise governance and institutionalism by passing the 'Full Stop Law' and 'Law of Due Obedience'. Next, Menem issued some pardons. Following this, the human rights organisations, while respecting democratic institutions, adopted a profile of confrontation with the public authorities.

From 2003 onwards, Kirchner created a completely different landscape by adopting the demands of human rights organisations as a focal point of his administration, and giving the state an active role in achieving truth, justice and memory. The 'Full Stop Law' and 'Law of Due Obedience' were declared unconstitutional, and the military trials were reopened. A National Archive of Memory was established, a National Genetic Data Bank was set up to identify children who had been seized during the dictatorship, and the identification of bodies by the Argentine Forensic Anthropology Team was improved. In a symbolic move, the government opened a Museum and Space of Memory in the Navy Mechanics School (ESMA) in Buenos Aires which had served as a clandestine detention and extermination centre during the military dictatorship.

At the same time, human rights became one of the bulwarks of Argentine foreign policy (Taiana 2003, 2008). In the UN, along with France, Argentina proposed an International Convention for the Protection of all People against Enforced Disappearances, and along with Switzerland, the establishment of a Special Rapporteur for the Promotion of Truth, Justice, Reparation and Guarantees of Non-Repetition. At the regional level, Argentina actively participated in the drafting of OAS Resolution 2662 entitled 'The Right to the Truth', which the OAS General Assembly approved in 2011 (OAS 2011; Ministry of Foreign Affairs and Worship 2013).

As regards domestic actors, several human rights organisations (including Mothers of Plaza de Mayo; Grandmothers of Plaza de 
Mayo; HIJOS, an organisation of the sons and daughters of the disappeared; and the Centre of Legal and Social Studies) succeeded in 'influencing' this policy, both in its domestic and its international dimensions. However, some human rights organisations, notably the Peace and Justice Service led by Adolfo Pérez Esquivel, complained that they had not been given a chance to participate in the policy process, which had been taken over by the government and certain organisations (Novaro 2008; Perfil 2008).

\section{The paper mills conflict}

Between 2005 and 2010, Argentina and Uruguay dealt with a conflict over the construction of two paper mills. It arose when Uruguay authorised the construction of two cellulose pulp mills in the binational waters of the Uruguay River, opposite the Argentine town of Gualeguaychú. One mill was meant to be built by the Spanish company ENCE, and the other by the Finnish company Metsa-Botnia. When the controversy arose, ENCE halted the project, but the Finnish mill was built and started to operate in November 2007.

From 2005 onwards, the inhabitants of Gualeguaychú as well as numerous environmental organisations mobilised against the construction of the mills on the grounds that they would pollute the river and affect the tourism trade. This led to growing demonstrations, including road blocks and blockades of the Libertador General San Martín bridge linking the two countries. Other environmental organisations, notably organisations based in Colón and Concordia, began to block other border crossings.

In May 2006, after months of unsuccessful negotiations with Uruguay, the Argentine government asked the International Court of Justice to suspend construction of the pulp mills in order to prevent harm to public health and the river environment. 
In a judgment handed down in April 2010, the ICJ found that Uruguay had violated the Statute of the Uruguay River, which stated that it should report to Argentina in good faith about any plans that could affect the river. However, the court ruled that Argentina's claim for the closure of the Botnia mill was disproportionate because there was no evidence that an increase in water pollution was caused by the mill, and it ordered both countries to collaborate on monitoring the state of the river via an Administrative Commission of the Uruguay River (CARU). The conflict ended in August 2010 with the signing of an agreement to establish a Scientific Committee within the Administrative Commission of the Uruguay River.

This was a special case, since the social demands were made by environmental organisations which mobilised against the project and repeatedly blocked the international bridge between 2005 and 2010; however, they succeeded in placing environmental issues on Argentina's domestic and international agendas. Néstor Kirchner did not act against these organisations; instead, he signalled his support by participating in a public event in Gualeguaychú in 2006.

In contrast with the past, in which the development model and political ideology were the basis for domestic influence over foreign policy, some analysts believe the president's stance in this instance was not motivated by the environmental claims as such but rather by his belief that domestic social conflicts should not be dealt with in a repressive manner. According to Escudé (2006: 4), 'Kirchner knew that repression against popular organisations of any kind such as the one so-called piqueteros, the environmentalists of Entre Ríos ... would lead to his government following the steps of De La Rúa ... That is why his strategy was ... Do not repress.' As a result, Kirchner dealt with the domestic role players in a diplomatic way, and reserved confrontational tactics for the international arena. 
This issue did not end well. The environmentalists were dissatisfied with the ruling by the International Court of Justice. Moreover, Argentina presented a divided stance on the bridge blockades, and relations with Uruguay deteriorated as a result.

As already seen, throughout Néstor Kirchner's tenure, foreign policy was influenced by domestic dynamics. This led to major confrontations with external actors, which were supported by Argentine citizens as they recognised that their interests were being defended. Therefore, progress was made with repairing the bond between state and society. Moreover, efforts to arrest the threatening state collapse resulted in various innovations in public policy. As noted by Palermo and Torre (1994), it is well known that the sense of urgency generated by social crises reinforces the insight that a lack of initiative can only make things worse, and that making a decision is more important than how it is made. Therefore, by the end of his administration, Néstor Kirchner enjoyed high levels of popular support, ${ }^{7}$ and a significant group of domestic actors supported his foreign policies.

That dynamic changed from 2008 onwards, under Cristina Fernández. The influence of domestic factors was even stronger during her presidency, not because progress had not been made towards resolving the Argentine crisis, but because her administration had to cope with more vigorous debates among and pressure exerted by domestic actors over foreign policy and domestic development. This led to renewed tensions between the state and civil society which was reflected in a series of disputes between the government and a range of economic, political, media and trade union actors.

This situation arose from a contradictory dynamic. On the one hand, the expectations of the private sector (productive, financial and media) were raised during Cristina Kirchner's election campaign. 
On the other, in order to make further progress with the politico-economic project, the government needed to take steps that worked against those interests.

In 2007, it was widely argued in the media that Cristina had a higher internationalist vocation than her predecessor. The big corporations, which had already recovered from the crisis, believed this presented them with an opportunity to return to the neoliberal paradigm. They assumed that the government, having improved the domestic political and economic situation, could renew its ties with traditional international actors (the IMF, the transnational financial sector, the USA and the EU) by setting aside the 'national density' approach which implied that wealthier actors had to make economic concessions in the interests of the public good.

The contradictions inherent in this situation were exposed during a conflict with rural producers in 2008. It comprised a dispute about grain export tariffs, or retenciones, which had various consequences. On the one hand, it worsened relations between the government and agricultural producers as well as the industrial sector, which supported the demands indirectly. On the other, it triggered a confrontation between the government and the corporate media, notably the Clarín group, which in 2008 depicted Argentina as a chaotic and confrontational society (Becerra and López 2009; Zunino and Aruguete 2010; Becerra 2015).

This confrontation, aggravated by the debate about the new Audio-Visual Law, increasingly preoccupied the government, and was taken up by the media as a means of 'overthrowing the government' (destituyente). ${ }^{8}$ It also became a vehicle for further opposition to the government by the urban middle classes. Thus, besides the agricultural strike ${ }^{9}$ and large numbers of road blocks, a middle-class sector emerged with claims about security, inflation, and institutionality, among others. This had two major 
consequences. First, the opposition parties not only supported the agricultural claims but also became the political voice of the media. Second, the vice-president and president of the Senate, Julio Cobos, eventually 'defected' and voted for the opposition. This deep-seated breach between the president and vice-president never closed.

The magnitude of this situation captured the government's attention for several months, forcing it to neglect the international agenda. Among other things, the president cancelled an official visit to China scheduled for January 2010 since she could not rely on the vice-president to serve as interim president in her absence. At the same time, foreign policy came under increasing fire from opposition parties, the media and some academics, who argued that the government was dealing with rural producers in the same adversarial way than with international challenges. In line with this, Cristina Kirchner's foreign policy was described as inconsistent and confrontational. $^{10}$

In all, the public supported a strategy of confrontation with external actors that had characterised Néstor Kirchner's administration, but did not support a strategy of confrontation with domestic actors, notably rural producers and the media. In this sense, society and the media were less tolerant of Cristina than of Néstor.

Growing internal political contestation became a 'domestic macro-conditionality' that began to threaten governance. Cristina Kirchner lost the parliamentary elections in 2009, but was strongly supported when Néstor Kirchner died in 2010 and was elected for a second presidential term in 2011, with 54\% of the vote. However, from 2013 onwards she had to cope with new opposition party victories in urban centres in mid-term elections, tensions with the judiciary, and heightened tensions between the government and the corporate media, the corporate sector, and opposition parties. Added to this were adverse changes in the international arena such as the 
global financial economic crisis of 2008, plunging global commodity prices from 2012 onwards, and difficulties encountered by other members of the 'Pink Tide', such as the crisis in Venezuela after the death of Hugo Chavez, the slowdown in the Brazilian economy, the decline in popularity of Michelle Bachelet's administration in Chile, and the loss of momentum of UNASUR.

Nevertheless, the government made decisions about issues regarded as intermestic, which, it claimed, supported the development model as well as Argentina's international interests. It nationalised the national airline, Aerolíneas Argentinas, as well as the retirement system, which until then was managed by private pension fund administrators (2008); implemented a second debt swap (2010); nationalised the National Petroleum Company (YPF), which had been managed by the Spanish company REPSOL (2012); reached a 'transnational agreement' with five companies which had received awards from the International Center for Settlement for Investment Disputes (ICSID) (2013); and signed a debt repayment agreement with the Club of Paris (2014).

Within this framework of 'domestic macro-conditionality', two events can be highlighted, with opposite results: a failed attempt to conclude a memorandum of understanding with Iran, and a decision not to comply with a decision by an American Court of Justice about payments to the Vulture Funds.

\section{Memorandum of understanding with Iran}

In 2013, Argentina and Iran signed a memorandum of understanding aimed at assisting investigations into the terrorist attack on the headquarters of the Argentina Jewish Mutual Association (AMIA) in 1994. Iranian citizens were thought to be responsible. Until 2013, Iran had systematically refused to co-operate with Argentina over 
the investigation. Cristina Kirchner's administration argued that the memorandum was a step forward as it would allow the establishment of a Commission of Truth, incorporating international jurists. It also stipulated that the Argentine justice system, represented by the judge Rodolfo Canicoba Corral and the prosecutor Alberto Nisman, could investigate the Iranian suspects. Despite strong opposition, the Argentine Congress approved the memorandum, but the Iranian parliament did not; as a result, it never entered into force.

Domestic factors played a significant role. First, the Jewish community was divided over the issue. The AMIA and the Delegation of the Argentine Jewish Association (DAIA) rejected the memorandum as they regarded it as unconstitutional, contrary to other Argentine laws, and a step backwards in the judicial investigations. They joined with the opposition parties and the corporate media in strongly criticising the agreement. Some political analysts have also claimed that these organisations articulated their position with the Israeli Embassy in Buenos Aires. ${ }^{11}$ On the other hand, the Association of Relatives and Friends of the Attack on AMIA and Active Memory agreed with the memorandum, and defended the initiative. As the memorandum was approved by the National Congress, opposition groups resorted to various judicial tactics until the First Chamber of the Federal Court accepted a request for protective action by AMIA and DAIA and declared it as unconstitutional.

In this instance, a sector of the Jewish-Argentine community collaborated with opposition parties and the media to oppose a foreign policy initiative proposed by the executive, and approved by Congress.

\section{The conflict with the Vulture Funds}

In 2010, Cristina Fernández succeeded in negotiating a second debt restructuring package, which raised the level of restructured debt to 
92.5\%. A group of creditors known as the Vulture Funds which were exposed to the remaining $7 \%$ did not accept the proposal, and placed their case before the Court of New York. In 2012, in a ruling widely criticised by specialists, ${ }^{12}$ Judge Thomas P Griesa found that these funds were entitled to collect $100 \%$ of the value of bonds, plus punitive interest. Because the Rights Upon Future Offers (RUFO) clause - which stipulated that any benefit given to a group of creditors should be extended to all - expired on 31 December 2014, the Argentine government appealed against the ruling, and decided not to comply with it as it would effectively drive the country into bankruptcy.

In October 2012, the Court of New York rejected the appeal, and in 2014 the Supreme Court of the United States declined to hear the case. This situation created renewed tensions between Argentina on the one hand and the USA and international financial sector on the other, and triggered a renewed attack on the Argentine government by the corporate media and big corporations, aimed at creating the impression that the country was heading for a new implosion. However, the government persisted with its approach, and did not make the required payments. It also retained public support by successfully explaining the negative consequences that compliance would have for the entire population.

\section{Conclusions}

The linkages between social demands and foreign policy during the Kirchner administrations did not emanate from the decentralisation of the decision-making process, but from the growing role of domestic factors in the wake of the 2001 economic crisis. Given this, the Kirchner governments approached foreign policy and Argentina's international insertion from a domestic point of view, aiming to foster a neodevelopmental economic model and autonomous international negotiations that would allow it to defend 
the needs and interests of the Argentine people, and consolidate an exit from the crisis. Consequently, Néstor Kirchner was supported by most of Argentine society in his confrontations with external actors such as the IMF, the World Bank, transnational corporations, the G7, and private bondholders. This support strengthened during conflicts with neighbouring countries.

Resorting to 'South Theories', and emphasising correspondences with other states forming part of the 'Pink Tide', foreign policy was mainly formulated by the executive, although agreed to by society. Referring to Oszlak and O'Donnell (1981), the state sought to guide its public policy (in this case, foreign policy) by reflecting the interests of civil society, as demonstrated by its efforts to restructure international debt without affecting employment and domestic development. Therefore, the interaction between state and society in this period had generally positive results. There were instances such as human rights policy and the paper mills issue - where foreign policy reflected specific social demands. In the former case, this happened in a co-operative way, and in the latter, via resistance and conflict.

Cristina Fernández's administration saw the growth of domestic confrontation, notably increased opposition from the productive and corporate media sectors. Although economic circumstances had improved, the threat of collapsing governance reappeared intermittently, while constant domestic political disputes became a 'domestic macro-conditionality' which increasingly influenced foreign policy, while not modifying its course. This conditionality intensified as the international context presented Argentine interests with increasingly complex scenarios.

For instance, decisions about foreign policy provoked a range of responses from civil society. Some foreign policy initiatives received social support, despite the strong opposition of corporations 
and media. This included the decision not to comply with the US court ruling about outstanding debt repayments, which later proved to be in the common good. At the same time, social conflict and resistance undermined some foreign policy initiatives, such as the memorandum of understanding with Iran.

In sum, we cannot assert that Kirchnerism embodied 'democratically oriented foreign policy' as a consequence of a systematic inclusion of domestic social demands, introduced by actors with a range of interests and power attributes. However, some domestic conditionalities were taken into account in the course of foreign policy formation. Consequently, the state's external actions to defend the population's economic, social and political needs and interests may be regarded as a first milestone on the road to democratising foreign policy.

\section{References}

Agramont, Ricardo Aguilar. 2012. 'Ni una molécula de gas para Chile'. La Razón. Political Section. 25 March. Available at: <http://www.la-razon.com/ index.php?_url=/suplementos/animal_politico/molecula-gas-Chile-vez_0_15 83241726.html> [accessed on 15 May 2013]

Baker, Pauline and John A Ausink. 1996. 'State collapse and ethnic violence: towards a predictive model'. Parameters US Army War College Quarterly, Spring: 19-31.

Becerra, Martín and Soledad López. 2009. 'La contienda mediática: temas, fuentes y actores en la prensa por el conflicto entre el gobierno y las entidades del campo argentino en 2008'. Ciencias Sociales UNQ Journal 2(16): 9-30.

Becerra, Martín. 2015. 'Transgresión, propaganda, convergencia y concertación. El sistema de medios en el Kirchnerismo'. In Carlos Gervasoni and Enrique Peruzzotti (eds) ¿Década Ganada? Evaluando el legado del Kirchnerismo. Buenos Aires: Debate, pp. 89-111. 
Belém Lopes, Dawisson. 2013. Política Externa e Democracia no Brasil. São Paulo: Editora Unesp (FEU).

Bermúdez, Ismael. 2003. 'El Nivel de pobres es cada vez más alto: \%7, $8 \%$ de la población', Newspaper Clarín [online], 1 February. Available at $<$ http://edant.clarin.com/diario/2003/02/01/e-00401.htm> [accessed on 3 October 2015].

Bulner, Thomas. 2003. The Economic History of Latin America since Independence. Cambridge: Cambridge University Press.

Busso, Anabella. 2010. 'Politica Exterior y Relaciones bilaterales con Estados Unidos durante el gobierno de Cristina: tensiones entre los objetivos de la campaña electoral y el renacer de los condicionantes internos'. In Alfredo Bruno Bologna (ed). La política Exterior de Cristina Fernández. Apreciaciones promediando su mandato. Rosario: UNR Editora, pp. 269-320.

2014. 'Los vaivenes de la política exterior argentina re-democratizada 1983/2013. Reflexiones sobre el impacto de los condicionantes domésticos'. Estudios Internacionales, IEI Universidad de Chile, 177: 9-33.

. 2015. 'La argentina kirchnerista ¿aislada o integrada? Reflexiones sobre la Política Exterior de la última década con especial referencia a los vínculos con Estados Unidos y América Latina'. In Carlos Gervason and Enrique Peruzzotti (eds) ¿Década ganada? Evaluando el legado del kirchnerismo, Buenos Aires: Debate-Universidad Torcuato Di Tella, pp. 271-299.

Borón, Atilio. 1983. 'Los problemas de la democracia en América Latina'. Journal Revista Mexicana de Política Exterior, December 1983: 17-29.

Corigliano, Francisco. 2007. 'Colapso estatal y política exterior: el caso de la Argentina (des)gobernada por Isabel Perón (1974-1976)'. SAAP Journal 3(1): 55-79.

Dandán, Alejandro. 2002. 'Cuando emigrar se convierte en una cuestión cultural'. Página 12 [online] (25/02). Disponible en <http://www.pagina12. com.ar/diario/sociedad/3-2253-2002-02-25.html> [accessed on 8 October 2015].

Della Roca, Mario. 2014. Gramsci en la Srgentina. Los Desafíos del Kirchnerismo. Buenos Aires: Duken.

De la Balze, Felipe. 2010. 'La política exterior de los gobiernos kirchneristas (2003-2009)'. Estudios Internacionales 166: 121-139. 
. 2011. 'Un país aislado'. Prensa Económica Journal 295. Available at <http://www.ancempresa.org.ar/pdf/articulo_de_la_balze_pais_aislado.pdf > [accessed on 8 October 2012].

Escudé, Carlos. 2006. 'El conflicto de las papeleras y la muerte de la política exterior'. Instituto de Seguridad Internacional y Asuntos Estratégicos del Consejo Argentino de Relaciones Internacionales Magazine 40 (9): 3-4.

Fernández Alonso, José. 2015. 'Política económica exterior Argentina: Consideraciones sobre la problemática de la inserción financiera internacional (2009-2014)'. In Bruno Bologna Bruno (ed). La política exterior de Cristina Fernández al finalizar su mandato. Rosario: UNR Editora, pp. 177-205.

Ferrer, Aldo. 2010. El futuro de nuestro pasado. La economía argentina en su segundo centenario. Buenos Aires: FCE.

Garretón, Manuel Antonio. 1982. 'En torno a discussao sobre os novos regímenes autoritáriosna América Latina’. Dados 25(2).

2006. 'Modelos y liderazgos en América Latina'. Nueva Sociedad Magazine 205: 102-113.

Kirchner, Néstor. 2003a. 'Discurso de Asunción del Presidente Néstor Kirchner', Buenos Aires. Available at <http://www.cfkargentina.com/ discurso-de-asuncion-del-presidente-Néstor-kirchner-a-la-asamblealegislativa-el-25-de-mayo-del-2003/> [accessed on 11 May 2015].

2003b. 'Discurso del ante la Asamblea General de Naciones Unidas', Nueva York. Available at <http://www.cfkargentina.com/discurso-de-Néstorkirchner-en-la-onu-2003/> [accessed on 12 May 2011].

Krugman, Paul. 2014. 'Krugman: Demanda de "fondos buitres" a Argentina es "descabellada", Portal Terra, Sección Economía. 14 November. Available at $<$ http://economia.terra.com.ar/krugman-demanda-de-fondos-buitres-a-argent ina-es-descabellada,340bfcd26e0b9410VgnCLD200000b2bf46d0RCRD.htm $1>$ [accessed on 12 May 2015].

Merke, Federico and Juan G Tokatlian. 2014. 'Instituciones y actores de la política exterior como política pública'. In Carlos Acuña (ed). Dilemas del Estado Argentino. Política Exterior, Económica y de Infraestructura en el siglo XXI. Buenos Aires: Siglo XXI, pp. 245-312.

Miguez, M Cecilia. 2013. 'El mito de la Argentina aislada en el mundo'. Perfil, 27 October. Available at <http://www.perfil.com/elobservador/El- 
mito-de-la-Argentina-aislada-en-el-mundo-20131027-0059.html> [accessed on 12 May 2014].

Menem, Carlos. 1990. Estados Unidos, Argentina y Carlos Menem. Buenos Aires: CEYNE.

Milani, Carlos and Leticia Pinheiro. 2012. Política Externa Brasileira: As práticas da política e a política das práticas. Rio de Janeiro: Editora FGV.

2013. 'Política Externa Brasileira: Os Desafios de sua Caracterização como Política Publica'.Contexto Internacional 35(1): 11-41.

Ministerio de Relaciones Exteriores y Culto de la República Argentina (MRECIC). 2013. 'Sistema Universal de Protección de Derechos Humanos de ONU'. Available at <http://www.mrecic.gov.ar/es/candidaturaargentina-al-consejo-de-derechos-humanos-2013-2015> [accessed on 5 May 2015].

Miranda, Roberto. 2001. 'El cambio externo y las estratégias internacionales de la Argentina. Relaciones Internacionales IRI-UNLP X(21): 169-195.

2012. 'Des-inserción argentina. Las políticas exteriores de Menem y Kirchner'. Enfoques Magazine XI(17): 85-103.

Novaro, Marcos. 2008. 'Derechos humanos y política democrática Las tareas de la historia y de la Justicia entre populismo y liberalismo'. In Pablo Eiroa and Juan Otero (eds). Memoria y Derecho Penal. Buenos Aires: Fabián Di Placido Editor, pp. 2-25.

Lafer, Celso. 2002. La identidad internacional de Brasil. Buenos Aires: Fondo de Cultura Económica.

Lasagna, Marcelo. 1996. 'Cambio institucional y política exterior: un modelo explicativo'. CIDOB d'Afers Internacionals 32: 45-64.

Lavagna, Roberto. 2005. 'Hacia otra dimensión de país'. Archivos del Presente 10(37): 37-38.

2014. 'Con la deuda, mejor el tifón que el tsunami'. Diario Clarín, Opinión, 24 July. Available at <http://www.clarin.com/opinion/deuda-mejortifon-tsunami_0_1180681991.html> [accessed on 27 October 2015] 
Neoliberal Crisis, Social Demands, and

Foreign Policy in Kirchnerist Argentina

Lima, María Regina Soares. 1994. 'Ejes analíticos y conflicto de paradigmas en la política exterior brasileña'. América Latina Internacional FLACSO, 1(2): 27-46.

2013. 'Relações Internacionais e Políticas Públicas: a contribuição da análise de Política Externa'. In Eduardo Marques and Carlos Aurélio Pimenta de Faria (eds). A Política Pública como Campo Multidisciplinar. São Paulo: Unesp Editora, pp. 127-153.

Organisation of American States (OAS). 2011. 'Resolución 2662 El derecho a la verdad '. General Assembly of the OAS, 41 Regular Session Period, San Salvador, El Salvador, 5-7 June 2011. Available at <http://www.oas.org/ consejo/sp/AG/resoluciones-declaraciones.asp> [accessed on 12 June 2011].

Oszlak, Oscar and Guillermo O’Donnell. 1981 .'Estado y políticas estatales en América Latina: hacia una estrategia de investigación'. In Documento Grupo de Estudio, CLACSO (4) Buenos Aires: Centro de Estudios de Estado y Sociedad.

Palermo, Vicente and Juan Carlos Torre. 1994. 'A la sombre de la hiperinflación. La política de reformas estructuras en la Argentina’. Centro de Investigaciones políticas (CIPOL), Documento de Trabajo. Available at $<$ www.cipol.org/pdfs/Palermo.pdf $>$ [accessed on 5 August 2013].

Perfil. 2008. 'Pérez Esquivel dijo que los Kirchner violan los Derechos Humanos y son iguales al menemismo'. Political Section. 18 October. Available at <http://www.perfil.com/politica/Perez-Esquivel-dijoque-los-Kirchner-violan-los-Derechos-Humanos-y-son-iguales-al-menemism o-20081018-0022.html> [accessed on 3 August 2014].

Pérez Llana, Carlos. 2010. 'Romper con el Aislamiento'. In Natalio Argentina Botana (ed). Entre la frustración y la esperanza. Buenos Aires: Taurus, pp. 131-182.

Pignatta, María Eva. 2010. 'Identidad y política exterior. Explorando el caso argentino'. In Anabella Busso (ed). Fuerzas profundas e identidad: Reflexiones en torno a su impacto sobre la política exterior. Rosario: UNR Editora, Tomo 2, pp. 139-157. Available at <http://www.cerir.com.ar/libro.php?id=0000142> [accessed on 9 June 2011].

Putnam, Robert. 1988. 'Diplomacy and domestic politics: the logic of two-level games'. International Organization 42(3): 427-459. 
Rapoport, Mario. 2010. Historia económica, política y social de la Argentina (1880-2003). Buenos Aires: Emecé (4th Edition).

Rosenau, James (ed). 1967. Domestic Sources of Foreign Policy. London: Collier-Macmillan.

Russell, Roberto. 1991. 'Variables Internas y Política Exterior'. In Workshop Cuestiones técnicas y metodológicas para el estudio de la Política Exterior, Buenos Aires, Argentina: FLACSO.

. 2008. 'La Argentina. Un país ausente y esperado'. Agenda Internacional. Una visión desde el Sur 4(15): 48-53.

Salazar Vargas, Carlos. 1995. 'Las políticas públicas'. Colección Jurídicas Profesores 19.

Simonoff, Alejandro. 2010. La Argentina y el Mundo frente al bicentenario de la Revolución de Mayo. Las relaciones exteriores argentinas desde la secesión de España hasta la actualidad. Part II. La Plata: Editorial UNLP.

Stiglitz, Joseph. 2013. 'Para Joseph Stiglitz, el fallo de la Cámara de Apelaciones por la deuda con los fondos buitre es "tendencioso", Clarín, Economic Section, 4 September. Available at http://www.ieco.clarin.com/ economia/Nobel-Jospeh-Stiglitz-justicia-tendencioso_0_986901666.html [accessed on 9 October 2013].

Taiana, Jorge. 2003. 'Derechos Humanos, política exterior y calidad democrática', La Nación, 10 December. Available at <http://www.lanacion. com.ar/553268-derechos-humanos-politica-exterior-y-calidad-democratica> [accessed on 3 August 2014].

_. 2008. 'El gobierno quiere que Argentina sea líder mundial en Derechos Humanos'. La Capital. Political Section. 4 March. Available at $<$ http://www.lacapital.com.ar/politica/El-gobierno-quiere-que-Argentina-sea -liacuteder-mundial-en-derechos-humanos-20080304-1002.html> [accessed on 3 August 2014].

Van Klaveren, Alberto. 1992. 'Entendiendo las políticas exteriores Latinoamericanas: modelo para armar'. Estudios Internacionales, IEI Universidad de Chile 98: 169-216.

Whitehead, Lawrence. 1993. 'The Alternative to Liberal Democracy: a Latin American Perspective'. In David Held (ed). Prospects for Democracy. Cambridge: Cambridge Polity Press, pp. 314-325.

Zunino, Esteban and Natalia Aruguete. 2010. 'La cobertura mediática del conflicto campo-gobierno. Un estudio de caso'. Global Media Journal Instituto 
Tecnológico de Monterrey 7(14): 1-23. Available at <http://www.redalyc. org/articulo.oa?id=68715085001> [accessed on 3 October 2015].

\section{NOTES}

1. Whitehead (1993) regards events in Latin America at that time as 'democracy by default'. Within this framework, the author establishes a relationship between politicisation and the neoliberal hegemony whose main purpose is to avoid 'populist instability'. Thus, neoliberalism could provide a form of democratic consolidation in which politicians retain high levels of depoliticisation while working on market reforms. Obviously, this kind of democratic consolidation would lack many of the features usually associated with the idea of liberal democracy (high levels of popular participation, choices among different political options, and extended citizens' rights).

2. Examples are the USA and other powers which acted (through sanctions, isolation or direct military intervention) against any political process that linked foreign policy with domestic changes in favour of social interests, as with Peronism in 1945, Guatemala in 1954, Cuba in 1959, the Dominican Republic in 1965, Chile in 1973, Nicaragua in 1979, and Granada in 1983.

3. His first and second ministers of economic affairs were Miguel Ángel Roig and Néstor Rapanelli, both former CEOs of Bunge \& Born, while other members of his cabinet were drawn from the Democratic Centre Union, a flagship right-wing political party.

4. Corigliano (2007) introduced the concept of state collapse as a means of analysing the impact of domestic factors on foreign policy during Isabel Martínez de Perón's administration. He suggested Baker and Ausink's article as a reference (1996).

5. '... Due to this national project, the Republic of Argentina will integrate into the world by taking steps towards political consensus based on the strengthening of the international law, the respect to our beliefs, history and domestic priorities. As advocates of the multilateral global policy, we support responsible, mature and reasonable relationships that respect the dignity of the countries instead of automatic alignments. Our priority about FP will be the construction of a Latin America that should be politically stable, prosperous, united, based on the ideals of democracy and social justice. Our intention is to deal with the main issues from a different perspective, by identifying 
appropriately the real problems of the social agenda (...) We see the world from our idiosyncrasy, from our own model' (Kirchner 2003a).

6. This included the enactment of the Law of the Preservation of Cultural Property in 2003; the automatic renewal of television licenses granted to the two biggest corporations, Clarín and Telefónica, in 2004; and the enactment of decree 527 in 2005, which suspended the ten-year computation of audiovisual licenses.

7. According to Poliarquía, the president's popularity was higher than $55 \%$ throughout his administration, comprising $76 \%$ in 2003; 66\% in 2004; $61 \%$ in 2005; 64\% in 2006 and 55\% in 2007. Meanwhile, according to OPSM/ Zuleta Puceiro, the Kirchner administration receivedmost support for its employment recovery programmes $84 \%$ acceptance), social programmes (77\%), educational programmes $(72.6 \%)$, foreign policy $(59.9 \%)$, and economic programmes (58.6\%). See http://www.elsiglodetorreon.com.mx/ noticia/315608.termina-kirchner-mandato-con-inedita-popularidad.html

8. This term (as well as 'soft coups') frequently appear in political analyses of Latin America as a reference to campaigns by the media and big corporations against democratically elected governments. In Argentina, they have been used regularly since the formation fo a group of intellectuals and other cultural figures called Carta Abierta. It was established at the time of the political and social confrontation between the government and rural producers (Della Roca 2014: 144). The document presented to the government before the outbreak of the conflict with the rural producers is available at http://www. pagina12.com.ar/diario/elpais/1-104188-2008-05-15.html.

9. The employer lockout lasted from March to June 2008, and involved road blocks which had a negative effect on the sales of agricultural products. Politically, the conflict affected the relationships between the government and rural producers from that moment until the end of Cristina Fernández's administration.

10. For characterisations of foreign policy under Cristina Fernández as inconsistent, confrontational and isolated, see De La Balze (2010, 2011), Pérez Llana (2010) and Russell (2008). For a less critical view, see Busso (2015), and a favourable one, see Miguez (2013).

11. According to the then Chancellor Héctor Timerman, before presenting the Memorandum of Understanding with Iran to Congress, he had been in contact with the different Jewish organisations in Argentina, which had understood its purpose and supported it. However, AMIA and DAIA rejected it later. According to Jorge Elbaum, this change of approach occurred due to the 
influence of domestic actors and the American and Israeli embassies. For Timerman's account of the meeting in the AMIA, see Material Audiovisual Visión 7, TV Pública Argentina, 'Attack on the AMIA: Timerman commented on the negotiations with Iran', 26 December 2012, at https://www. youtube.com/watch?v=2RLWnRGH_kU. For the Chancellor's presentations to the External Relations Commission of the Deputy Chamber about the ongoing dialogue and communication with representatives of the Jewish community, see Material Audiovisual Canal C5N, 'Timerman in the annex of the Deputies (part I)', 6 February 2012, at https://www.youtube.com/ watch?v=jo4eJ2D4d8I. For Jorge Elbaum's analysis, see 'Vultures, Nisman, DAIA: the money trail', Newspaper Página 12, 18 April, 2015, at http://www.pagina12.com.ar/diario/elpais/1-270831-2015-04-18.html [all accessed on 2 October 2015].

12. Criticism of Judge Griesa's decision was related to his interpretation of the pari passu clause. Lavagna (2014), Fernández Alonso (2015), Stiglitz (2013) and Krugman (2014) agreed that this was erroneous. Although Argentina's attempt to refer Judge Griesa's decision to the US Supreme Court failed, numerous countries, organisations, and well-known actors introduced an amicus curiae supporting Argentina. They included France, Mexico, Brazil, Joseph Stiglitz, Anne Krueger, the G77, Puente Investment Bank, the American Bankers Association, the Clearing House and the Euroclear, among others. Finally, Griesa's decision and its negative impact on the process of debt renegotiation prompted Argentina to table a resolution in the UN General Assembly containing a series of guiding principles for the restructuring of sovereign debt. It was approved in September 2015 by 136 in favour, 6 against and 41 abstentions.

\section{About the Author}

Anabella Busso is a researcher at the National Council of Scientific and Technical Research (CONICET) in Argentina. She heads the Research Institute of the School of Political Science and International Relations at the National University of Rosario, and is a professor of international politics and Latin American foreign policy at the same university. She also teaches graduate courses at other institutions in Argentina and abroad. She specialises in Argentine foreign policy, American foreign policy on Latin America, and relations between Argentina and the USA. She is the vice-president of the Argentina Society of Political Analysis. 